\title{
静止性骨空洞の総合画像診断について
}

\author{
小笠原利行・石井保雄・林 解平・伊東俊祐 \\ 西出直人・玉井 学・岩佐昌典 $\cdot$ 大野屋雅宽 \\ 斎藤諭・西村 毅*
}

\section{Combined diagnostic imaging of static bone cavities}

\author{
Toshiyuki Ogasawara $\cdot$ Yasuo IshiI $・$ Kaihei Hayashi \\ Syunsuke Ito $\cdot$ Naoto Nishide $\cdot$ Manabu TAmai \\ Masanori Iwasa $\cdot$ Masahiro Oonoya $\cdot$ Satoru SAIto \\ Takeshi Nishimura*
}

\begin{abstract}
Computed tomography (CT), CT-sialography and ultrasonography (US) were performed in 3 cases of static bone cavity.

1. Axial CT sections clearly demonstrated defects of the lingual cortex of the mandible.

2. In all three cases, CT-sialography clearly showed a lobulated submandibular gland which occupied the bone defect.

3. US performed in two of the patients, clearly detected the bone defect. The contents in the bone defect were also clearly detected; the internal echo of the contents was hyperechoic and heterogeneous. US was thereby confirmed to be a useful examination for this disease.

Both CT-sialography and convertional sialography were performed in one case to compare differences in the resulting images. Convertional sialography did not clearly demonstrate the spatial relationship between the submandibular gland and bone defect in contrast to CT-sialography. We attributed this difference to mandibular position during the X-ray.

One case in which the buccal cortex at the lesion was thin and distended underwent surgery. The intraoperative and histopathological findings were found to match the diagnostic imagings.
\end{abstract}

Key words: static bone cavity (静止性筲空洞), CT-sialography (CT ジアログラフィー), ultrasonography（超音波検査）

\section{緒言}

静止性骨空洞は, 臨床的には無聇状で全身疾患とも無

福井医科大学歯科口腔外科学講座

（主任：石井保雄教授）

* ユニチカ中央病院米科

（主任：西村 毅）

Department of Dentistry and Oral Surgery,

Fukui Medical School (Chief: Prof. Yasuo Ishii)

* Department of Dentistry, Yunitika Central Hospital (Chief: Takeshi Nishimura)

受付日：平成 4 年: 8 月 12 日
関係に生じ，下顎角前下方部にみられる襄胞様骨欠損で あり，1942年，Stafne ${ }^{1)}$ が最初に報告して以来，現在ま で多くの報告がみられる。

欠損部の陥入内容物は唾液腺組織をはじめ, 脂肪組 織, リンパ組織, 結合組織, 筋肉, 血管など種々の存在 が確認されているが，本症の成因拉よび病態てついては いまだ明確にされていない。

本疾患の画像診断法としては従来より単純X線, 靧下 腺造影による診断が主体を占めて扣り，最近では CT よる検索の有用性が報告されている。

今回, 著者らは本症の 3 例について, 従来の撮影法に 加え, 超音波, CT, CT sialography を用いた総合画像 診断を行い,さらに，1例については観血的処置の機会 

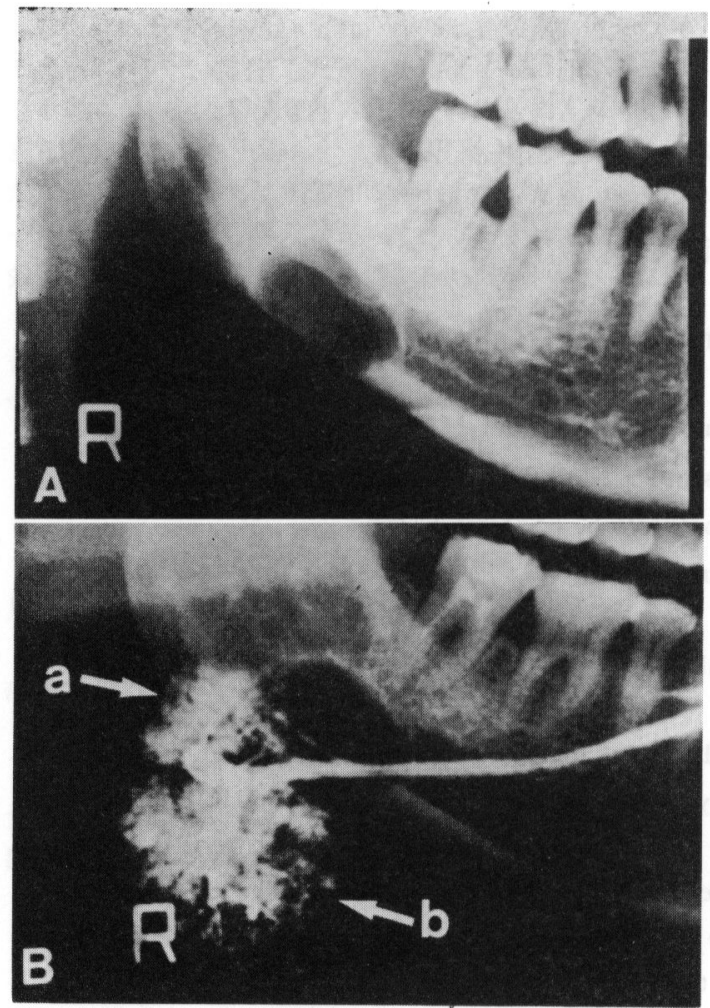

写真 1 症例 $1 \mathrm{~A}$ : オルソパントモグラフィー所見 B : 顎下腺造影所見

（a：副顎下腺, b : 顎下腺体)

を得たので, 先の結果との比較検討を含め若干の考察を 加光て報告する。

症 例

\section{症例 1}

患 者: 49歳 女性.

初 診: 昭和60年 6 月回.

主 訴：右下顎部X線透過像の精查.

既往歴・家族歴：特記事項なし。

現病歴：昭和 60 年 5 月, 7 | 疼痛のため某歯科医院を 受診, デンタル X 線写真で $\overline{7} \mid$ 根尖部滖胞様透過像を 認め, 歯根囊胞の疑いで当科を紹介受診した。

現 症

全身所見：体格，栄養状態ともに良好。

局所所見：顔貌左右対称，右側䫈下リンパ節特よび右 下䫇角部の発赤, 腫脤, 压痛はなく, またオトガイ部の 知覚異常など, 神経障害も認められなかった。

画像所見 :

(1) オルソパントモグラフィー所見

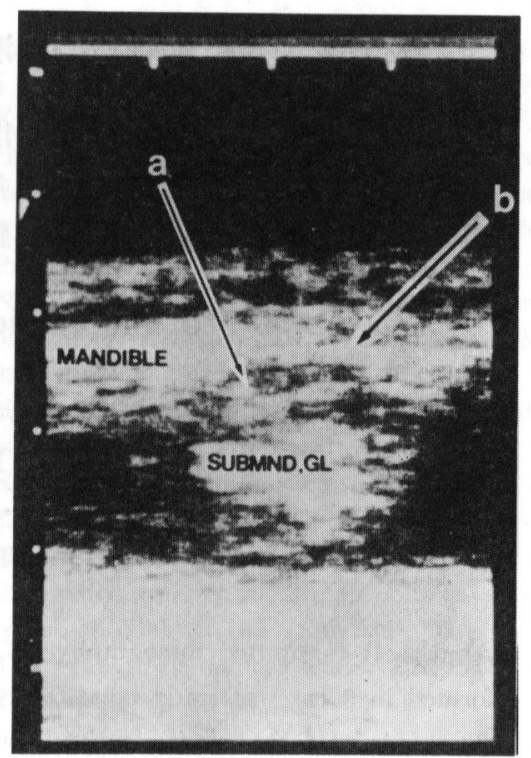

写真 2 症例 1 超音波所見

(a : 副顎下腺，b：下顎骨骨㫟四)

右下顎角前方部に 1 層の骨硬化帯を有する拆指頭大, 単胞性で下部外形線 $1 / 3$ 欠損するX線透過像を認めた. 下歯槽管の連続性は保たれて招り，骨欠損部に执いては 煩舌方向への圧排が 疑われた。. 7 | 崡槽硬線との連続し た所見は認められなかった（写真1 $\mathbf{A}$ ).

（2）超音波所見

下䫇骨下縁舌側部の骨辺縁は陥凹した弧線として描画 され，その内に比較的境界明膫な heterogeneous な䋶下 腺の小分葉像が描出された（写真 2).

(3) 顎下腺造影所見

a) オルソパントモグラフィー所見

顎下腺造影像ではワルトン管は下顎骨 $\mathrm{X}$ 線囊胞様透過 像の下方を後方に走り, 顎下腺体部は囊胞様透過像の後 方で上下に大小の 2 分様を呈し，ワルトン管より上後方 に分岐した副導管と小分葉が認められた。 上方に位置す る分葉は下顎骨下部の囊胞様透過像内への陷入像は認め られなかった（写真 $1 \mathbf{B}$ ).

b ) CT-sialography 所見

上記の顎下腺造影直後, CT 撮影を施行した。右下顎 角前下方舌側骨壁部に 骨欠損が 確認され，そのなかに enhance された二分葉の顎下腺体の小分葉が陷入した画 像が鮮明に描出された（写真了）.

臨床診断：右下顎骨静止性骨空洞.

処置および経過：上記画像診断の結果より，骨久損部 外側皮質骨は十分な厚みをもち，病的骨折など招来する 危険性がないと判断し, 以後, X線撮影にて定期的経過 観察を行っているが, 骨欠損部の変化は全く認められな 
认.

\section{症例 2}

患 者: 60歳 女性.

初 診: 平成 2 年 8 月回.

主 訴: $\underline{7}$ | 抜霜依頼.

既往歴・家族歴：特記事項なし.

現病歴 : 某歯科医院より 7 拔歯依頼にて当科を紹介 受診した.

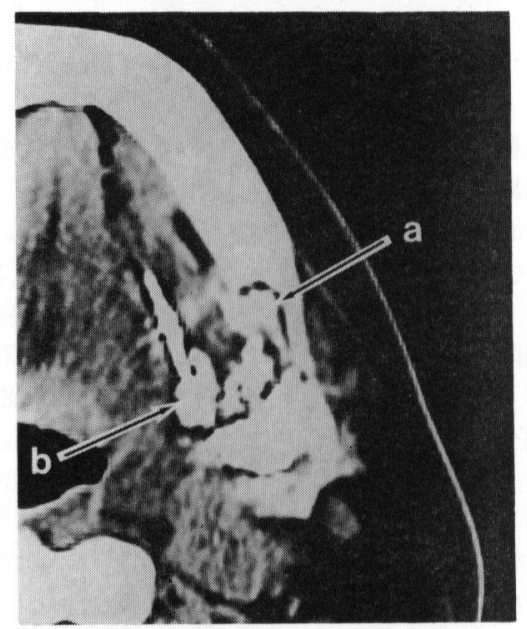

写真 3 症例 $1 \mathrm{CT}$ ジアログラフィー所見 （a：副顎下腺， b : 顎下腺体）
現 症

全身所見：体格，栄養状態ともに良好.

局所所見：7| 慢性歯根膜炎の局所症状を認めるほか, 顔貌左右対称, 左顎下リンパ節, 左下顎角部に異常所見 ならびに自覚症状なく, オトガイ部の知覚異常など, 神 経症状も認められなかった。

画像所見

(1) オルソパントモグラフィー所見

口内精査のため, オルソパントモグラフィーを撮影. 左下顎角前方部に 1 層の骨硬化帯に囲まれた拇指頭大, 半円形単胞性で下部外形線が欠損したX線透過像を認め た。骨透過像上方にはX線透過性の高い下雨槽管の近接 する像が認められた（写真 4 ）。

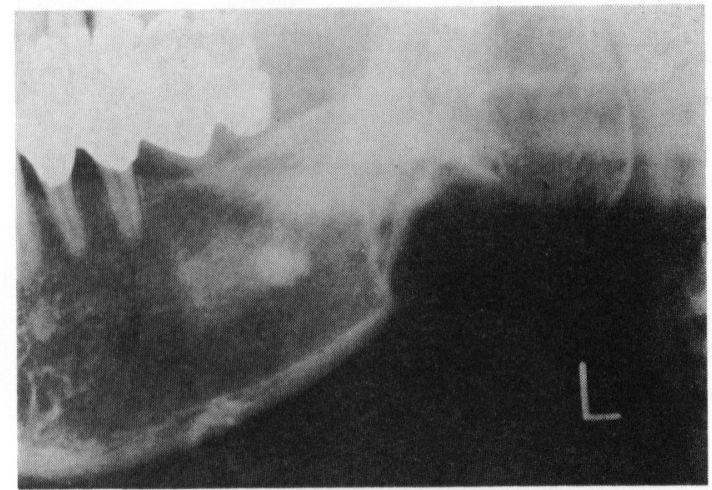

写真 4 症例 2 オルソパントモグラフィー所見

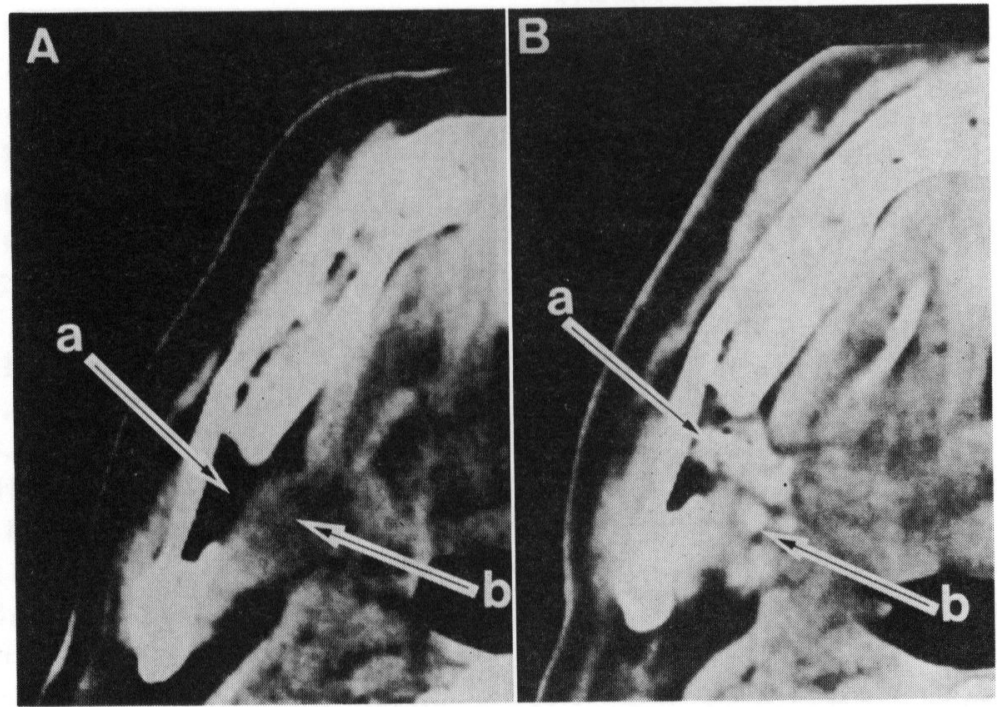

写真 5 症例 2 A : CT 所見

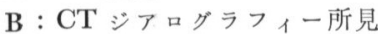

（a：副顎下腺， b ：顎下腺体） 


\section{(2) CT 所見}

左側下靧角前下方の舌側骨壁部には，舌側に開放し， 顎骨内部へ拡大した骨欠損像を認めた。骨欠損部内には low density mass で満たされていた。 な抔煩側の骨皮質 はやや菲薄になっているものの頓側方向への膨隆などの 骨変化像は認められなかった（写真 $5 \mathbf{A}$ ).

(3) 顎下腺造影所見

a ) CT-sialography 所見

骨欠損部内に enhance された分葉状の顎下腺体の陥 入像が描画されたが，欠損部後方部に扣いては，low density area が認められた (写真 5 B).

臨床診断：左下顎骨静止性骨空洞.

処置および経過：上記診断にて，以後定期的に経過観

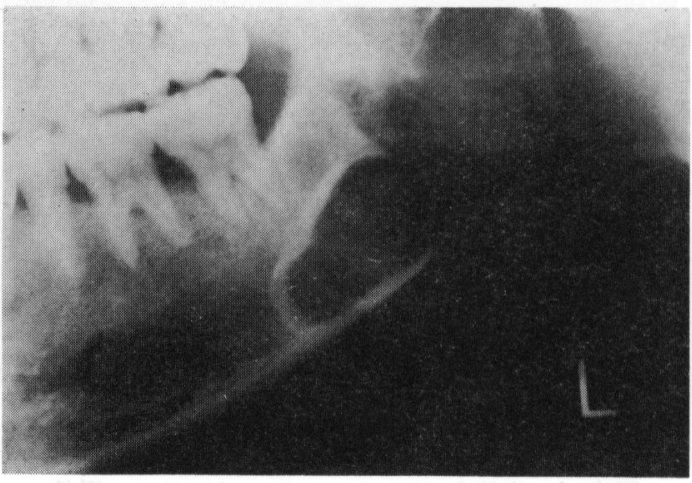

写真 6 症例 3 オルソパントモグラフィー所見
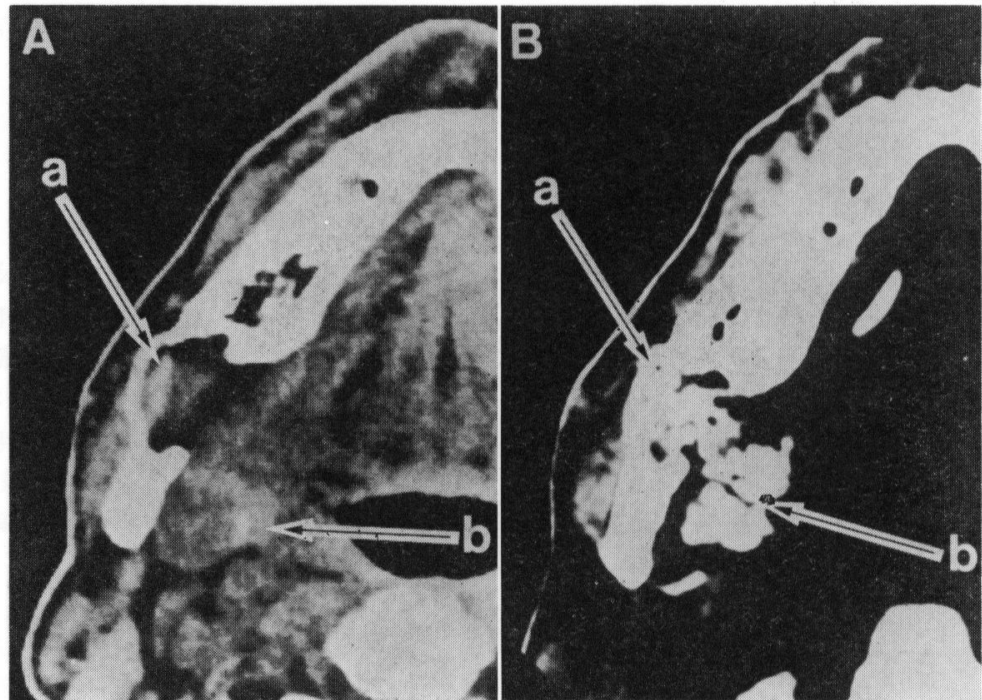

写真 8 症例 3 A : CT 所見

$\mathrm{B} ： \mathrm{CT}$ ジアログラフィー所見

（a：副顎下腺， b : 顎下腺体) 
既往歴：糖尿病にて現在通院加療中.

家族歴：特記事項なし。

現病歴： $\underline{5}$ 万蝕加療のため某歯科受診. 同医のオル ソパントモグラフィーで, 左下䫇骨部に囊胞様X線透過 像を認め, 精查のため当科を紹介受診した.

\section{現 症}

全身所見：体格，栄盖状態ともに良好で，空腹時血桾 は91〜120にコントロールされている.

局所所見 : 左下罰角部に境界明膫な骨様硬の腫脹が触 知されるが, 局所の発赤, 圧痛, オトガイ部の知覚麻痺 などの他覚的，自覚的な異常所見は認められなかった．

\section{画像所見 :}

(1) オルソパントモグラフィー所見

左下顎角部前下方部に拇指頭大で，周囲は 1 層の骨硬 化帯により囲まれ楕円形単胞性の骨透過像が認められ た。骨透過像部では下歯槽管は上方に 圧排されていた (写真 6 ).

\section{（2）超音波所見}

下䫇骨舌側骨縁に sonolucent な弧線として描画され た骨欠損部が認められ，先の内に heterogeneous な顎下 腺の小分葉像が描出され, さらにその内側に顎下腺体部 が描画された（写真 7 ).

(3) CT 所見

左下顎角前下方舌側骨壁部に舌側に開放した骨欠損が 認められ，頓側の骨皮質は菲薄化し外側飞膨隆してい た。 また骨欠損部内には軟組織と思われる low density mass の陥入像が認められた（写真 $8 \mathbf{A}$ ).

（4）䫈下腺造影所見

a ) CT-sialography 所見

骨欠損部内全体飞 enhance された多分葉の䫇下腺組 織の陥入像が垫められ，単純 CT でみられた骨欠損部内 の軟組織像の形態と一致していた（写真 8 B ）.

臨床診断：左下顎骨静止性骨空洞.

処 置：上記画像診断の結果より, 骨欠損部頓側皮質 骨が菲薄であり, 病的骨折を招来する可能性が危惧され たため, 手術適応と考光全身麻醉下で摘出術を施行し た。

手術所見：骨欠損部内には正常喠液腺と連絡した分葉 状副䋶下腺を認め, 久損部頓側皮質骨は菲薄で暗紫色を 呈していた。術中，骨欠損部と唾液腺との位置関係を検 討するために下顎骨を前方に率引すると骨欠損部内の顎 下腺は内側後方飞移動牽引されて可動性を認め, 顎骨欠 損部内は空隙を生じた（写真 $9 \mathbf{A}$ )。陥入している副顎 下腺を顎下腺体部より結紮，切離して除去した。な拈， 菲薄な頗側皮質骨は除去し，欠損部内にはフィブリン接 着剂（ベリプラスト $\mathrm{P}{ }^{\circledR}$ ) を用いて，人工骨の結晶化ガ ラス顆粒を填塞した（写真 9 B).

摘出物所見：大きさ $18 \times 20 \mathrm{~mm}$, 弾性軟, 多分葉を 呈する顎下腺組織であった（写真10A）.

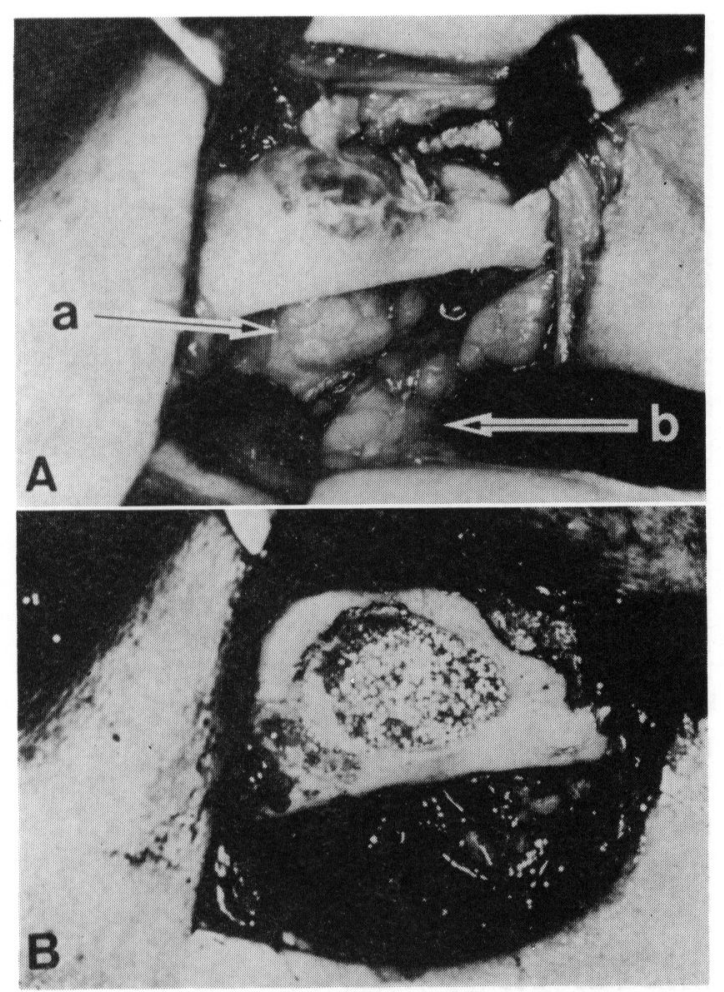

写真 9 症例 $3 \mathrm{~A}$ ：手術所見

B : 結晶化ガラス填塞時所見

（a：副顎下腺， b : 顎下腺体）

病理組織所見：正常買下腺組織（写真10B）.

経 過: 術後, 左オトガイ部に軽度の知覚異常が認め

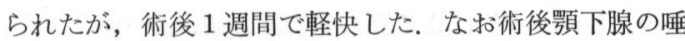
液分泌機能飞 異常所見は認められない. 術後 3 か月の CT 像では填塞した結晶化ガラス顆粒は安定, 硬化し良 好な経過が認められ現在経過観察中である（写真11）。

$$
\text { 考察 }
$$

本症は, Stafne ${ }^{1)}$ が1942年に, 臨床的に無症状で下靧 骨体部にX線上，囊胞様透過像を呈した 34 症例に対し， "bone cavities situated near the angle of the mandible" と題して報告したのが最初である。名称に関しては, static bone cavity2,3), developmental bone defect $t^{4,5)}$, latent bone cyst $^{6,7)}$, lingual mandibular bone cavity ${ }^{8,9)}$, aberrant submandibular gland tissue in the mandible ${ }^{10,11)}$ などと報告者によりさまざまで，いまだ統一さ れていない。乙かし, 囊胞腔を有さない下䋶骨舌側の骨 陥凹であるという点で見解は一致している。

発生頻度は, オルソパントモグラフィーにより検索し た本邦拉よび諸外国の報告 ${ }^{3,5,12,13)}$ とよると，207〜372 


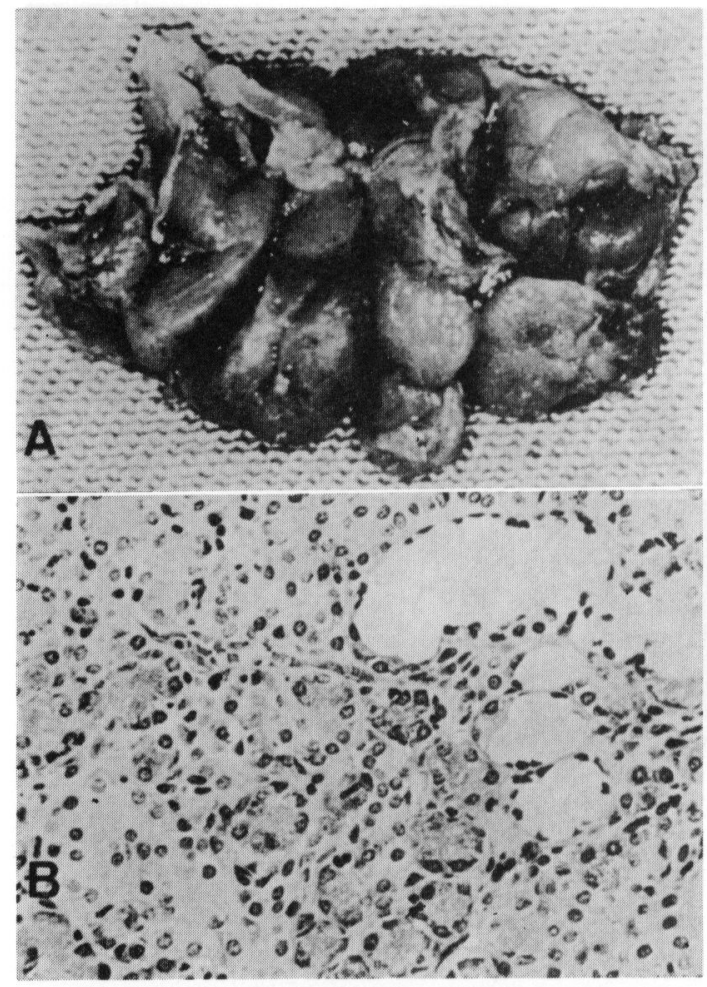

写真 10 症例 $3 \mathrm{~A}$ : 摘出物所見

B : 病理組織所見 $(\times 100)$

例飞 1 例とそれほどまれな疾患ではないとされてきてい る.

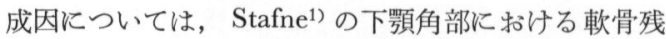
遗説, Fordyce ${ }^{14)}$ 飞上る顎の発育異常説, Jacobs ${ }^{15)}$ の顎 骨形成期の隣接軟組織飞よる組織陥入説, Thoma ${ }^{7}$ の動 脈瘤説, Rushton $5^{16)}$ の sclitary bone cyst の圧迫残遗

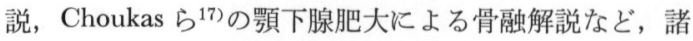
説報告されいまだ定説をみないが，現在では後天的に周 用軟組織により骨への圧迫吸収によって生じるとする意 見 ${ }^{7,17 \sim 19)}$ が大半の上らである。

今回著者らが経験した 3 例は, 全例, 副顎下腺の形成 および顎下腺体の肥大が認められた。成因としてはまず 先天的汇副䫇下腺の形成異常が存在し, 肥大した副顎下 腺の圧迫と次いで唾液分泌機能の变化など骨へのなんら かの 後天的要因として 長期間の骨への 圧迫刺激が加わ り，局所的骨吸収を生じたものと推測された。

本症は大部分が，無症状で機能障害や異常などを認め ないため, 画像診断においては一般X線撮影によるもの が主体であったが，唾液腺との関連性を検索するため 1960年, Seward ${ }^{20}$ とょり顎下腺造影が施行され，Oikarinen $ら^{21)}$ や田畑ら ${ }^{22)}$ は, ステレオ撮影による嵿下腺造 影を試みている。

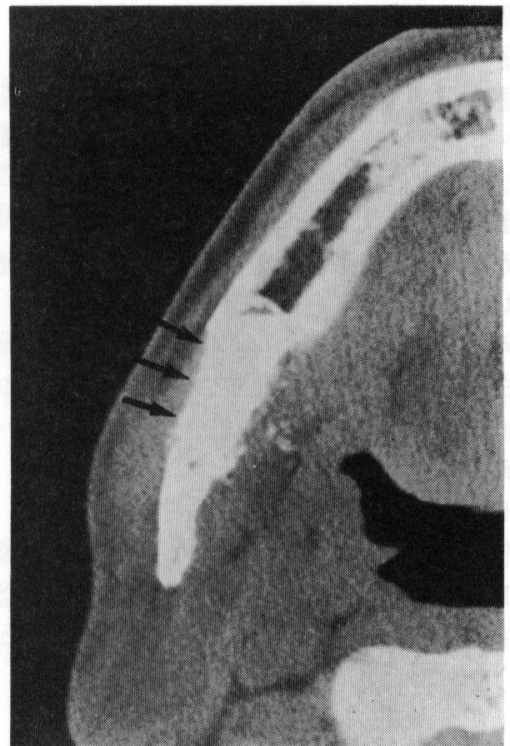

写真 11 症例 3 術後 3 か月 $\mathrm{CT}$ 所見

この㴿下腺造影検査の有用性に関しては従来より多数

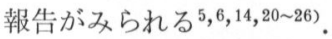

一方, 竹之下 ${ }^{27)}$ や D' Eramo ら ${ }^{28)}$ は, 造影検査で は明膫に診断できなかったと報告している。また， Seward ${ }^{20)}$ や有地 ${ }^{29)}$ は単純造影倹查の側面像では, 顎骨 々腺体とが重複するため両者の関係を把握するために は，咬合撮影や斜位像など多方向からの検索が必要であ ると述べている。

最近では，CT による検索が有用であるとの報告もみ られる ${ }^{23}$ が，実際に， CT 像を供覧報告しているものは 少なく $\left.{ }^{23} 25,29,30\right)$, さらに CT-sialography を呈示したも のとしては, 有地ら ${ }^{299}$, 井上ら ${ }^{30)}$ の報告をみるに過ぎな い.

今回著者らは 3 症例に対し $\mathrm{CT}$ 検查を施行し, 症例 1 については, 従来の顎下腺造影との比較を行うため顎下 腺造影後, オルソパントモグラフィーと, CT の両者に よる検查を施行した。 その結果, CT-sialography に特 いては, 骨陌山内の腺体組織の造影像を明膫飞描画し得 たが, オルソパントモグラフィーでは腺体の陥入は認め られなかった。

今回のオルソパントモグラフィーと CT-sialography との所見の相違は, 症例 3 の術中所見の結果より,オル ソパントモグラフィー撮影時, 下頒を切端咬合位まで前 突させるためにそれに伴う顎下腺組織を含む軟組織の後 下方への移動によるものと考兄られ，撮影時の下顎位に ついても考慮する必要があると思われた。 その点, CT 撮影時では安静仰臥位で下顎骨周囲軟組織が生理的な状 態を保持しつつ撮影することが可能であり，上記の問題 
点は解消されるものと思われた。 また，本症の特徵であ る下顎骨舌側に開放した骨欠損の描出 ${ }^{29)}$ ，さらにその内 に顎下腺造影像が明膫に陷入している像を描画でき, 将 態の把握执よび他の類似疾患との鑑别が容易であった。

近年口腔領域の各種疾患に対して非侵襲的で簡便であ

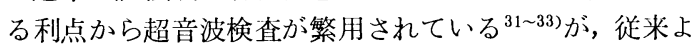
り一般に軟組織に対する検查法として用いられて和り, 硬組織疾患に対する応用 ${ }^{33)}$ は少ないようである. 今㠲著 者らは本症に対し検索を試みたが，下顎骨骨欠損状態, 陥入内容物执よび両者の関係を簡便に描画でき, 本症の 疑いに際して CT-sialography に先がけ first choice と しての有用性が涩められた。

骨陷凹内内容物に関しては，本邦報告例の 文献的集 計 ${ }^{18,29,34,35)}$ によると, 唾液腺組織が大多数を占め他にリ ンパ組織, 脂肪組織, 結合組織がみられ, 諸外国では, 血管7), 筋組織8) などが報告されている. 今们の著者ら の治験例では, 超音波検査および CT による画像診断の 結果から，3症例とも分葉状を呈した副靧下腺組織の陥 入が認められた。特に症例 3 に打いては, 外科的処䈯の 結果, 手術所見扣よび病理組織学们所見と画像診断は一 致した結果が得られた。

以上, 本症の診断として単純X線検查により本症が疑 われた場合，さらに超音波，CT により骨陷凹状態を 3 次元的に把握し, 陷四内内容物の確認については顎下腺 組織が大半であることより, 著者らは CT-sialography による併用が臨床診断上きわめて有用であると考えてい る。また，陷凹内内容物が唾液腺以外であった場合にお いても, 今後 CT 值の計測 ${ }^{29,30)}$, 超音波検查による症例 の蓄積により内容物の推定が 可能になると思われる.

CT のスライス方向については症例 3 のように久損部頓 側皮質骨が膨隆, 非薄化している症例の場合, 今後発育 増大する可能性を示唆しており, 本症の病態の把握には 矢状面よりも水平面に扐ける尙火損部の観察が重要と思 われる。

本症の処置に関しては, Stafne ${ }^{1)}$ は， 5 症例につき， 11年間の経過観察を行い骨欠損部の大きさに変化は認め られなかったと述べ，後に Tolman ら"4 であった 2 例で， 1 例は 7 年後， 1 例は10年後に本症の 出現を認めたと報告しているが，一般的に機能障害や自 覚症状を認めなければその処置は必要なく，X線的に経 過観察を行うとする意見 ${ }^{22,24,26,34,35)}$ が大半のようであ る.しかし, 内容物が多形性腺腫であったという Simpson $ら^{36)}$ の報告や, 最近では外科的摘出後, 火損部の化 骨形成を認めたといら報告 ${ }^{37)}$ みられる．著者らの症例 3 のように発育増大傾向を示唆しているものは“developmental bone defect” の名称が示す状態であり, 従来 の static な状態とは病態が異なり注意を要するものと思 われた.

そこで, 本症の病態と陷入内容物との関係を検璟する
ため, 過去の報告例のらち著者らが 渉猟し得た範囲で developmental な病態を示し, かつ内容物の確認を行 ったもの 9 例の内在組織をみると, 正常唾液腺組織 4 例 ${ }^{14,38 \sim 40)}$, 脂肪組織 2 例 ${ }^{29)}$, 多形性腺腫 1 例 $^{36)}$, 粘液腺 組織 1 例 ${ }^{41)}$, 筋組織 1 例 ${ }^{42)}$ と多彩であった. 少数例では あるがこの結果より, 病態と陷入内容物には特定の関連 性は認められなかったが，いずれにせよ本症の成因に関 して明確でない現在, static なものか, developmental なものかを的確に画像診断などで鑑別する必要があり, もし後者であった場合は積極的な治療も許容されると著 者らは考えている。

\section{結} 語

静此性省空洞の 3 例に対し，CT，CT-sialography， 超音波による総合画像診断を施行し, 下顎骨欠損部内に 副顎下腺の小分葉の陥入像が認められた。 さらに，1例 については観血的処置を行い, その術中所見と画像診断 所見は一致した絬果が得られた。

\section{引用文 献}

1) Stafne, E.C.: Bone cavities situated near the angle of the mandible. J Am Dent Assoc 29: 1969-1972 1942.

2) Bernstein, H.F., Lam, R.C., et al.: Static bone cavities of the mandible: review of the lieterature and report of case. J Oral Surg 16: 461958.

3) Karmiol, M. and Walsh, R.F.: Incidence of static bone defect of the mandible. Oral Surg 26: 225-228 1968.

4) Tolman, D.E. and Stafne, E.C.: Developmental bone defects of the mandible. Oral Surg 24: 488-490 1967.

5) 江原昌弘, 内海潔, 他：いわゆる Developmental bone defect の24症例のエックス線写真 的検索. 歯放 17: 44-51 1977 .

6) 西鸡克巳, 友沢 基, 他: いわゆるLatent bone cyst の 1 例. 日口外誌 15: 205-208 1969.

7) Thoma, K.H.: Case report of a so called latent bone cyst. OS OM OP 8: 963-966 1955.

8) Olech, E. and Arora, B.K.: Lingual mandibular bone cavity. Oral Surg 14: 1360-1366 1961.

9) Hansson, L.: Development of a ligual mandibular bone cavity in an 11-year-old boy. Oral Surg 49: 376-378 1980.

10) Stene, T. and Pederson, K.N.: Aberrant salivary gland tissue in the anterior mandible. Oral Surg 44: 72-75 1977. 
11) Araiche, M. and Brode, H.: Aberrant salivary gland tissue in the mandible. Oral Surg 12: 727-729 1959.

12) Correll, R.W., Jensen, J.L., et al.: Lingual cortical mandibular defects. Oral Surg 50: 287-291 1980.

13）佐藤 畺, 小松久高, 他：いわゆる Developmental bone defect エックス線学的観察. 岡山 歯誌 3: 127-131 1984.

14) Fordyce, G.L.: The probable nature of socalled latent haemorrhagic cysts of the mandible. Brit Dent J 101: 40-42 1956.

15) Jacobs, M.H.: The traumatic bone cyst. OS OM OP 8: 940-949 1955.

16) Rushton, M.H. and Cantab, B.Ch.: Solitary bone cysts in the mandible. Brit D J 81:37491946.

17) Choukas, N.C. and Toto, P.D.: Etiology of static bone defect of the mandible. J Oral Surg 18: 16-20 1960.

18）伊藤輝夫, 兽我宏世, 他：下顎限局性骨欠損招 よび骨腔の臨床病態とその成因に関する考察。 口科誌 23：441-451 1974.

19) Harvey, W. and Noble, H.W.: Defects on the lingual surface of the mandible near the angle. Br J Oral Surg 6: 75-83 1968.

20) Seward, G.R.: Salivary gland inclusions in the mandible. Brit Dent J 108: 321-325 1960.

21) Oikarinen, V.J., Wolf, J., et al.: A stereosialographic study of developmental mandibular bone defects(Stafne's idiopathic bone cavity). Int J Oral Surg 4: 51-54 1975.

22）田畑修, 黒木敬士, 他：顎下腺造影により確 認された“Static Bone Defect”の一例。菌放 22: 348-349 1983.

23) Shiratsuchi, Y., Tashiro, H., et al.: Posterior lingual mandibular bone depression. J Oral Maxillofac Surg 15: 98-101 1986.

24) 高谷康男, 西嶋克巳, 他 : Idiopathic Bone Cavity の 2 症例 およびその文献的考察. 口科誌 34: 225-232 1985.

25) Uemura, S., Fujishita, M., et al.: Radiographic interpretation of so-called developmental defect of mandible. Oral Surg 41: 120-127 1976.
26）飯野ゆき子，草刈潤，他：い水ゆる Static bone defectの 1 症例. 耳喉 49: 645-651 1977.

27）竹之下康治，友寄喜樹，他：下顎骨の後方舌側 骨陷山 (Stafne's idiopathic bone cavity) につ いて。 日外誌 25: 1457-1468 1979.

28) D'Eramo, E.M. and Poidmore, S. J.: Developmental submandibular gland defect of the mandible: Review of literature and report of a case. Oral Surg 39: 14-19 1975.

29）有地栄一郎，田畑修，他：いわゆる Stafne's bone cavity 3 例の CT に上る検索. 口科誌 37: 303-314 1988.

30）非上照夫，井田端枝：CT-Sialographyによる 静止性骨空洞の観察。米放 25：22-23 1985.

31) Chodosh, P.L., Silibey, R., et al.: Diagnostic use of ultrasound in diseases of the head and neck. The Laryngoscope 90: 814-821 1980.

32) Shawker, T.H., Sonies, B.C., et al.: Soft tissues anatomy of the tongue and floor of the mouth: An ultrasound demonstration. Brain and Language 21: 335-350 1984.

33）小林明男：顎骨疾患に関する超音波医学的研 究。日口外誌 30：257-273 1984 .

34）和田 明，林 洋紀，他：静止性骨空洞の 6 例. 日只外誌 30：185-191 1984 .

35）大谷端夫，泉 誠一，他：いわゆるStatic bone defectの 3 症例. 日口外誌 26: 804-809 1980.

36) Simpson, W.: A Stafne's mandibular defect containing a pleomorphic adenoma: report of case. J Oral Surg 23: 553-556 1965.

37）池本公亮，石川武憲，他：Stafne 氏静止性骨空 洞の 2 症例。 日口外誌 35：2716-2722 1989 。

38）偷科慧治，北和田信吾，他：Static bone cavity の 1 例. 口科誌 27: 69-73 1978 .

39）作藤泰則, 埜口五十雄, 他：顎下腺造影により 部断した静止性骨空洞の 1 例。 日口外誌 34: 1437-1443 1988.

40）柴田 敀，汇良謙次，他：増大傾向を示した静 止性骨空洞に対する手術後の経過(抄)，日口診 誌 2: 2731989.

41) Camilleri, G.: Salivary gland inclusion in the mandible. Brit Dent J 114: 515-516 1963.

42）古川博雄, 岩瀬雅彦, 他：腫瘍を疑わしぬた静 止性骨空洞の 1 例（抄)。 日口外誌 $34: 2331-$ 23321988. 